\title{
Orchard Groundcover Management Impacts on Apple Tree Growth and Yield, and Nutrient Availability and Uptake
}

\author{
Ian A. Merwin ${ }^{1}$ and Warren C. Stiles ${ }^{2}$ \\ Department of Fruit and Vegetable Science, Cornell University, Ithaca, NY 14853

\begin{abstract}
Additional index words. orchard floor management, weed control, herbicide, straw mulch, living mulch, plant nutrition, micronutrients, Malus domestica, tree fruit
\end{abstract}

\begin{abstract}
This study compared various conventional and alternative orchard groundcover management systems (GMSs) including a crownvetch "living mulch" (CNVCH), close-mowed (MWSOD) and chemically growth-regulated (GRSOD) sodgrasses, pre-emergence (NDPQT) and two widths of postemergence (GLY1.5 and GLY2.5) herbicides, hay-straw mulch (STMCH), and monthly rototillage (tilled)_during 6 years in a newly established apple (Malus domestica Borkh.) planting. Trunk cross-sectional area and fruit yield were higher in STMCH, GLY, and NDPQT, intermediate in tilled, and lower in GRSOD, MWSOD, and CNVCH treatments after 5 years. Despite N and K fertilizer applications, extractable soil $N$ and leaf $N$ concentrations were reduced under MWSOD and GRSOD, and soil $K$, $P$, and $B$ concentrations were greater under STMCH. Leaf K concentrations were usually highest in STMCH trees, even when heavily cropped; leaf $K$ declined below the sufficiency range in GLY, NDPQT, and tilled trees as they began to bear fruit. Leaf Ca was marginally deficient in all trees and was unaffected by GMS. Foliar Mn, Zn, and B concentrations declined rapidly in all treatments during 2 years without micronutrient fertilizers. Leaf $\mathrm{Cu}$ was higher in herbicide and tilled treatments where seasonal soil water content was intermediate $(22 \%$ to $27 \%$ ) and lower where soil was very wet or dry for most of the 1988 growing season. Multiple regression analysis indicated that leaf $N$ and $B$ and soil organic matter in 1990, and mean soil water content during the unusually dry Summer 1988, were the best predictors of fruit yield in 1990. Phytophthora root rot and meadow vole depredation were serious problems in STMCH and CNVCH trees. GMSs greatly affected tree establishment, nutrition, and yield; each system involves tradeoffs among important short- and long-term impacts on the orchard agroecosystem.
\end{abstract}

Increasing attention is being paid to orchard floor management in order to minimize weed competition and bring today's highly capitalized plantings into full production more quickly. In the humid regions of North America and Europe, herbicided tree rows with mowed-grass drive lanes have become the most common orchard groundcover management system (GMS). Past studies have demonstrated that tree growth, productivity, and nutrient uptake during orchard establishment are maximized at least cost by herbicide GMSs (Haynes, 1980; Hogue and Neilsen, 1987). Currently, serious questions are being asked about the long-term sustainability of herbicide usage (National Research Council, 1989) and the possibility that alternative systems using different groundcover species or management strategies might provide some of the soil conservation benefits of vegetative ground coverage without excessive weed-crop competition (Skroch and Shribbs, 1986). Several studies of orchard floor management have also indicated the need for more information about specific effects of GMSs on critical factors such as micronutrient availability and uptake by fruit trees (Atkinson and White, 1981; Haynes, 1980; Hogue and Neilsen, 1987). In 1985, we initiated a long-term field experiment to evaluate the relative impacts of alternative orchard GMSs on apple tree growth, nutrient uptake and yield, soil physical conditions and fertility, and the apple pest complex. The effects of

\footnotetext{
Received for publication 22 June 1992. Accepted for publication 25 June 1993 Cornell Univ. Dept. of Fruit and Vegetable Science paper no. 29. This research was supported in part by USDA-CSRS Hatch Project NY(C)-142409. We gratefully acknowledge the assistance of Michael Moracco and Richard Reisinger in conducting this research and the critical reviews of the manuscript by Marvin P. Pritts and H. Christian Wien. The cost of publishing this paper was defrayed in part by the payment of page charges. Under postal regulations, this paper therefore must be hereby marked advertisement solely to indicate this fact.

${ }^{1}$ Assistant professor.

${ }^{2}$ Professor.
}

eight different GMSs on soil physical conditions and water availability have been reported elsewhere (Merwin, 1990; Merwin et al., 1994). In this article we report the portion of this study pertaining to tree growth and yield and nutrient availability and uptake during the first 6 years.

\section{Materials and Methods}

The experiment was established in a former apple orchard site at Ithaca, N.Y., which had been without trees during the previous 8 years and was not fumigated before replanting. The soil is a Hudson silty-clay loam (mixed mesic Udic Hapludalf) with 2\% to $6 \%$ slopes. At the beginning of this study, mean topsoil organic matter content was $53 \mathrm{~g} \cdot \mathrm{kg}^{-1}$ and $\mathrm{pH}$ was 5.8. In Apr. 1985, a 70:30 mixture of 'Elka' perennial ryegrass (Lolium perenne L.) and 'Ensylva' creeping red fescue (Festuca rubra L.) was seeded at 50 $\mathrm{kg} \cdot \mathrm{ha}^{-1}$ over the entire site with an oat (Avena sativa $\mathrm{L}$. cv. Astro) nurse-crop. In Apr. 1986, alternate rows of 'Empire' and 'Jonagold' apple on MM.111 rootstock were planted in augered holes, spaced $3 \mathrm{~m}$ within rows and $6 \mathrm{~m}$ across sod alleyways. GMS treatments were randomly assigned to strips centered on the tree rows in experimental units of eight adjacent trees, in a blocked design (split by apple cultivars) with six replications of the following: 1) $\mathrm{CNVCH}-\mathrm{a} 2.5$-m-wide "living mulch" leguminous groundcover of 'Penngift' crownvetch (Coronilla varia L.); 2) GLY1.5-a 1.5m-wide killed-sod strip provided by annual applications of $N$ (phosphonomethyl) glycine (glyphosate) at a rate of $2 \mathrm{~kg}$ a.i. per treated hectare each May and July; 3) GLY2.5-a 2.5-m-wide glyphosate killed-sod strip, provided as above; 4) NDPQT - a 2.5$\mathrm{m}$-wide strip of bare ground provided by annual applications of 4chloro-5-(methylamino)-2-(3-(trifluoromethyl) phenyl)-3(2H )pyridazinone (norflurazon), $\mathrm{N}$ - (3,4-dichlorophenyl)- $\mathrm{N}, \mathrm{N}$ dimethylurea (diuron), and 1,1'-dimethyl-4,4'-bipyridinium ion 
(diuron) tank-mixed at 3.0, 2.5, and $0.5 \mathrm{~kg}$ a.i. per treated hectare, respectively, each May; 5) MWSOD - the sodgrass mixture of red fescue and perennial ryegrass, mowed to maintain a height of 6 to $10 \mathrm{~cm}$; 6) GRSOD - a 2.5-m-wide strip of the same sodgrass mixture, treated annually in May and July with the growth suppressant 1,2-dihydro-3, 6-pyridazinedione (maleic hydrazide) applied at $5 \mathrm{~kg}$ a.i. per treated hectare, and a broadleaf selective herbicide 2,4-dichlorophenoxyacetic acid (2,4-D amine) applied at $1.5 \mathrm{~kg}$ a.i. per treated hectare during 1986-89; beginning in 1990 an ultra-low rate of glyphosate $(0.2 \mathrm{~kg}$ a.i. per treated hectare) was substituted for the previous GRSOD treatment in these plots; 7) STMCH-a 2.5-m-wide hay-straw mulch strip $15 \mathrm{~cm}$ deep $(30 \mathrm{~kg} /$ tree), renewed annually in May; and 8) tilled - a 2.5-m-wide cleancultivated strip provided by rototilling to $10 \mathrm{~cm}$ deep monthly, May through August each year.

Before establishing the experiment, $12 \mathrm{Mg}$ of dolomitic lime per hectare was applied to the site. During the initial year, $\mathrm{NH}_{4} \mathrm{NO}_{3}$ was broadcast over the entire orchard floor at the rate of $140 \mathrm{~kg} \mathrm{~N} /$ ha in early June. During subsequent years, supplemental nutrients were provided by foliar application and/or distribution in a circular pattern beneath each tree. In 1986, K was applied at $56 \mathrm{~kg} \cdot \mathrm{ha}^{-1}, \mathrm{Mg}$ at $35 \mathrm{~kg} \cdot \mathrm{ha}^{-1}, \mathrm{~B}$ at $1.7 \mathrm{~kg} \cdot \mathrm{ha}^{-1}$ to soil and $0.7 \mathrm{~kg} \cdot \mathrm{ha}^{-1}$ in foliar applications, Zn-EDTA chelate in four foliar applications totalling $0.7 \mathrm{~kg} \cdot \mathrm{ha}^{-1}$, and $\mathrm{Cu}$ at $0.9 \mathrm{~kg} \cdot \mathrm{ha}^{-1}$ in prebloom fungicides. In 1987 and $1988, \mathrm{~N}$ (as $\left.\mathrm{NH}_{4} \mathrm{NO}_{3}\right)$ was applied at $100 \mathrm{~kg} \cdot \mathrm{ha}^{-1}(0.15 \mathrm{~kg} /$ tree $)$, and applications of $\mathrm{K}, \mathrm{Mg}, \mathrm{B}, \mathrm{Zn}$, and $\mathrm{Cu}$ were continued as in 1986. In 1989 and 1990, $\mathrm{N}$ (as $\mathrm{NH}_{4} \mathrm{NO}_{3}$ ) was applied at 167 $\mathrm{kg} \cdot \mathrm{ha}^{-1}(0.25 \mathrm{~kg} /$ tree $)$, but all other nutrient fertilizers were discontinued in order to better detect the relative impacts of each GMS treatment on nutrient availability.

In mid-August each year, soil cores were augered from 0 to 20 and 20 to $40 \mathrm{~cm}$ deep in four locations between trees (avoiding locations where fertilizers had been applied to soil) in each plot and composited for analysis. Soil organic matter content was determined by loss on ignition at $500 \mathrm{C}$ for $2 \mathrm{~h}$. Soil $\mathrm{pH}$ was measured in a 1 soil : 1 water solution. Soil nutrient concentrations were determined by extraction in Morgan's solution at a 1 soil : 5 solution ratio, and analysis by atomic absorption flame spectrometry; water-soluble B was extracted by boiling in a $0.125 \%$ solution of barium chloride (Greweling and Peech, 1965).

In early August each year, four recently matured lateral shoot leaves were removed from different sides of the six center trees in each plot and composited for determination of foliar nutrient concentrations. Leaf samples were oven-dried in paper bags at 90C to reach constant weight and ground in a Wiley mill. Nitrogen concentrations were then analyzed by a Kjeldahl procedure. Other elements were extracted from dry-ashed samples in ammonium acetate, and concentrations on a dry weight basis were determined by using an inductively coupled argon-plasma spectrograph (model 975 Plasma Atomcomp with ICAP 61 Update; Jarrell-Ash, Pittsburgh). Trees were trained to a modified vertical axe system with minimal pruning, and fruit were not thinned. Data were subjected to analysis of variance and multiple regression using the Statview and SuperANOVA statistical packages (Abacus Concepts, Berkeley, Calif.). The treatment $\times$ year interaction was significant in most years $(P<0.05)$, while the treatment $\times$ cultivar interaction was not. For most of the statistical analyses, data for the two apple cultivars were therefore pooled, while treatment effects were determined individually within years.

\section{Results}

Trunk cross-sectional areas (TCSAs) $30 \mathrm{~cm}$ above the scionrootstock union did not differ at the time of planting or after the first growing season in 1986 (Table 1). After the second growing season (1987), TCSA differed significantly among treatments, ranking in the order STMCH > NDPQT $\geq$ GLY2.5 $\geq$ GLY1.5 $\geq$ tilled $\geq \mathrm{CNVCH}>$ GRSOD $\geq$ MWSOD. Relative TCSA rankings remained remarkably constant during subsequent years, except for trees in $\mathrm{CNVCH}$, which lagged behind others after the crownvetch became fully established in 1987. Relative trunk growth rate (RGR), calculated each growing season as $\left[\log \left(\right.\right.$ TCSA $\left._{\text {final }}\right)-$ $\log \left(\right.$ TCSA $\left.\left._{\text {initial }}\right)\right] / 0.150$ days, exhibited a different trend (Table 1). There were no treatment differences in the first year, but in 1987 treatments ranked STMCH > NDPQT $=$ GLY2.5 > GLY1.5 $\geq$ tilled $=\mathrm{CNVCH}>$ GRSOD $>$ MWSOD. However, in 1988 the RGR of trees in $\mathrm{CNVCH}$ was significantly lower than all other treatments, which were equivalent. In subsequent years, there were no detectable treatment effects on annual RGR, despite the sustained differences in cumulative TCSA.

Trees in all treatments produced a few apples in 1988 (Table 1). Because of winter injury to flower buds (attributed to a rapid freeze of $-30 C$ in Dec. 1988), there was a negligible crop in 1989, although trees in STMCH and NDPQT produced more fruit. The

Table 1. Yearly increase in trunk cross-sectional area (TCSA), relative growth rate (RGR), and fruit yield per tree from 1986 to 1991 among different groundcover management systems (GMSs).

\begin{tabular}{|c|c|c|c|c|c|c|c|c|c|c|c|c|c|c|c|c|c|c|}
\hline \multirow[b]{2}{*}{ GMS } & \multicolumn{6}{|c|}{$\operatorname{TCSA}\left(\mathrm{cm}^{2}\right)$} & \multicolumn{6}{|c|}{$\operatorname{RGR}\left(\mathrm{cm}^{2} \cdot \mathrm{day}^{-1}\right) \times 1000^{\mathrm{z}}$} & \multicolumn{6}{|c|}{ Yield (kg/tree) } \\
\hline & 1986 & 1987 & 1988 & 1989 & 1990 & 1991 & 1986 & 1987 & 1988 & 1989 & 1990 & 1991 & 1986 & 1987 & 1988 & 1989 & 1990 & 1991 \\
\hline $\mathrm{MWSOD}^{\mathrm{y}}$ & 5.2 & 8.0 & 13.7 & 23.8 & 33.1 & 44.4 & 0.7 & 1.2 & 1.6 & 1.6 & 0.9 & 0.8 & 0 & 0 & 0.10 & 0.20 & 9.11 & 10.02 \\
\hline GRSOD & 5.2 & 8.4 & 15.0 & 26.6 & 36.9 & 48.4 & 0.5 & 1.4 & 1.7 & 1.6 & 0.9 & 0.8 & 0 & 0 & 0.04 & 0.18 & 8.87 & 10.51 \\
\hline $\mathrm{CNVCH}$ & 4.8 & 9.6 & 14.1 & 24.0 & 32.5 & 41.3 & 0.5 & 2.0 & 1.1 & 1.5 & 0.9 & 0.6 & 0 & 0 & 0.12 & 0.59 & 9.52 & 8.04 \\
\hline STMCH & 5.2 & 12.7 & 22.0 & 37.6 & 48.9 & 62.0 & 0.7 & 2.6 & 1.6 & 1.6 & 0.8 & 0.6 & 0 & 0 & 0.02 & 2.69 & 21.20 & 10.73 \\
\hline Tilled & 5.0 & 10.0 & 17.3 & 30.8 & 41.1 & 51.4 & 0.5 & 2.0 & 1.6 & 1.7 & 0.8 & 0.6 & 0 & 0 & 0.03 & 0.15 & 13.79 & 9.01 \\
\hline GLY1.5 & 4.9 & 10.3 & 18.4 & 32.1 & 41.3 & 52.5 & 0.5 & 2.1 & 1.7 & 1.6 & 0.7 & 0.7 & 0 & 0 & 0.11 & 0.54 & 20.85 & 9.94 \\
\hline GLY2.5 & 4.9 & 11.0 & 19.5 & 35.2 & 45.2 & 58.2 & 0.6 & 2.3 & 1.7 & 1.7 & 0.7 & 0.7 & 0 & 0 & 0.10 & 0.30 & 22.38 & 10.12 \\
\hline NDPQT & 5.0 & 11.1 & 20.2 & 34.3 & 44.2 & 56.2 & 0.6 & 2.3 & 1.7 & 1.5 & 0.7 & 0.7 & 0 & 0 & 0.23 & 1.38 & 21.37 & 10.00 \\
\hline $\operatorname{LSD}_{(P \leq 0.05)}{ }^{\mathrm{x}}$ & NS & 1.2 & 1.6 & 3.3 & 3.6 & 6.3 & NS & 0.2 & 0.2 & NS & NS & NS & NS & NS & NS & 1.00 & 3.78 & NS \\
\hline
\end{tabular}

${ }^{\mathrm{z}}$ Relative growth rate calculated as $\left[\log \left(\mathrm{TCSA}_{\text {final }}\right)-\log \left(\mathrm{TCSA}_{\text {initial }}\right)\right] / 0.150$ days, where $\mathrm{TCSA}_{\text {initial }}$ and TCSA final $_{\text {are values at the beginning and end }}$ of each 150-day growing season, for each successive year.

'Treatment abbreviations: GLY1.5 and GLY2.5 = glyphosate herbicide strip, 1.5- and 2.5-m-wide; CNVCH = crownvetch "living mulch"; NDPQT = norflurazon + diuron + paraquat herbicides; MWSOD = mowed sod-grass; STMCH = hay-straw mulch; GRSOD = growth-regulated sod; and tilled $=$ rototilled.

${ }^{x}$ Protected LSD for means of six replicates per treatment; NS = nonsignificant. 
first major crop was harvested in 1990, and fruit production on a per-tree basis ranked GLY2.5 $\geq$ NDPQT $\geq$ STMCH $\geq$ GLY $1.5>$ tilled $>\mathrm{CNVCH} \geq \mathrm{MWSOD} \geq$ GRSOD. Yields in 1991 were considerably reduced in those treatments that had produced the highest yields the previous year, and there were no differences among treatments. Tree mortality after 6 years in $\mathrm{CNVCH}$ and STMCH (14\% and $38 \%$ respectively) was much greater than in other treatments, because of root disease caused by Phytophthora spp. (Merwin et al., 1992) and depredation by meadow voles (Microtus pennsylvanicum). Yield on a per-hectare basis in the CRNVCH and STMCH treatments would therefore be lower than the per-tree values (Table 1), since trees that died were not included in subsequent yield-per-tree calculations. The yield efficiency of trees varied linearly with TCSA-larger trees also produced more kilograms of fruit per unit TCSA. 'Jonagold' trees were larger than 'Empire' but the yield efficiency was greater for 'Empire'; hence the cumulative yields of both varieties were equivalent.

Concentrations of essential nutrients and soil $\mathrm{pH}$ in the upper 20 $\mathrm{cm}$ of soil were affected by GMS (Table 2). Extractable nitrates were greater in tilled and STMCH soil than in the two sodgrass GMSs after 5 years. Soil P increased substantially under STMCH, and decreased or remained unchanged under all other treatments from 1986 to 1990 . Soil K increased by $\approx 75 \%$ under most GMSs, but was more than eight times greater in STMCH soil after 5 years. With the exception of soil Mn and B, extractable concentrations of the minor elements generally appeared to be unaffected by GMS. Soil Mn decreased in all treatments from 1986 to 1990, but was higher under STMCH than NDPQT and GLY1.5 in 1990. Soil B declined in all treatments when foliar and soil-applied B fertilizers were discontinued in 1989 and 1990 (Fig. 1), but there was less of a decline under STMCH. Soil pH increased by 0.3 to 0.9 units under all treatments from 1986 to 1990 , but treatment effects on $\mathrm{pH}$ were absent (Table 2).

Leaf $\mathrm{N}$ concentrations were lower in MWSOD and GRSOD trees in 1987 and 1990 (Table 3), and were below desired ranges in most GMSs during 1989 and 1990 (Stiles and Reid, 1991) despite supplemental $\mathrm{N}$ fertilization. The hypothetical $\mathrm{N}$-fixation by root nodules of the $\mathrm{CNVCH}$ legume was not evident in apple leaf $\mathrm{N}$ concentrations during any year. Four-year-average leaf $\mathrm{P}$ content was higher in trees in MWSOD, and GRSOD, intermediate in $\mathrm{CNVCH}$ and STMCH, and lower in tilled and herbicide treatments, although foliar $\mathrm{P}$ concentrations were considered adequate in all GMSs. Average leaf K values were highest in the STMCH trees during most years, and generally within optimal ranges in all GMSs until the trees began to bear fruit (Table 3). With the first harvestable crop in 1990, leaf K decreased in the three herbicide and tilled treatments, but remained higher in STMCH and sodgrass treatments. Leaf $\mathrm{Ca}$ was below recommended levels in all treatments during every year despite preplant liming of the site, and $\mathrm{Ca}$ uptake appeared unaffected by GMS. Leaf $\mathrm{Mg}$ concentrations were lower in STMCH trees, a result we attributed to the elevated leaf and soil $\mathrm{K}$ concentrations in this treatment (Tables 2 and 3 ).

Foliar concentrations of micronutrients differed among GMS treatments during some years (Table 4). Foliar Mn and Zn concentrations were probably confounded by residues of these elements in the dithiocarbamate (EBDC) fungicides applied to the orchard during 1988. The highest concentrations were observed in $\mathrm{CNVCH}$ trees, which also had the least increase in TCSA (Tables 1 and 4). Foliar Mn and Zn concentrations declined in all GMSs from 1988 to 1990, when applications of EBDC fungicides were discontinued in 1989. No differences in leaf Fe were observed among GMS treatments. Foliar $\mathrm{Cu}$ concentrations were lower in MWSOD and GRSOD trees during 1987 and higher in GLY, NDPQT, and tilled trees during 1988. Regression analysis indicated that leaf $\mathrm{Cu}$ concentrations reflected soil water content averaged over the 1988 growing season (Fig. 2). Foliar $\mathrm{Cu}$ was higher in treatments where gravimetric soil water content averaged $22 \%$ to $27 \%$. Leaf $\mathrm{Cu}$ and B fell below critical levels in all GMSs during 1989 and 1990, with the cessation of foliar micronutrient applications and the advent of heavier cropping.

The relationship between yield per tree and selected variables affected by GMS treatments was analyzed using a backwardforward elimination stepwise-multiple-regression model, with Fto-enter or remove set at 4.0 (Table 5). Twenty-four variablesincluding leaf and soil nutrient concentrations in 1990, soil organic matter content in 1990, and average seasonal soil water content during the 3 years preceding the first harvestable crop-were evaluated as predictors of fruit yield. Only four predictor variables_-soil water content during the drought year of 1988, leaf $\mathrm{N}$ and $\mathrm{B}$ in the current crop year, and soil organic matter contentremained in the final regression model. The correlation coefficients among these four variables were not significant at $P<0.05$; we therefore considered them sufficiently independent for multiple regression.

\section{Discussion}

The impacts of grass and legume groundcovers on tree size and fruit production in this study confirm previous reports of the critical importance of weed suppression in establishing deciduous

Table 2. Extractable concentrations of nutrients and soil $\mathrm{pH}$ in the upper $20 \mathrm{~cm}$ of orchard soil after 5 years under different groundcover management systems, and the changes in extractable soil concentrations of these nutrients from 1986 to 1990.

\begin{tabular}{|c|c|c|c|c|c|c|c|}
\hline GMS & $\begin{array}{l}\mathrm{NO}_{3}-\mathrm{N}^{2} \\
\mathrm{~kg} \cdot \mathrm{ha}^{-1}\end{array}$ & $\begin{array}{c}\mathrm{P}( \pm \text { change }) \\
\mathrm{kg} \cdot \mathrm{ha}^{-1}\end{array}$ & $\begin{array}{c}\mathrm{K}( \pm \text { change }) \\
\mathrm{kg} \cdot \mathrm{ha}^{-1}\end{array}$ & $\begin{array}{c}\mathrm{Ca}( \pm \text { change }) \\
\mathrm{kg} \cdot \mathrm{ha}^{-1}\end{array}$ & $\begin{array}{c}\mathrm{Mg}( \pm \text { change }) \\
\mathrm{kg} \cdot \mathrm{ha}^{-1}\end{array}$ & $\begin{array}{c}\text { Mn ( } \pm \text { change }) \\
\mathrm{kg} \cdot \mathrm{ha}^{-1}\end{array}$ & $\mathrm{pH}( \pm$ change $)$ \\
\hline$\overline{\text { MWSOD }}^{y}$ & 6.3 & $5.7(-5.8)$ & $209(+93)$ & $3487(-100)$ & $396(-62)$ & $35(-38)$ & $6.7(+0.6)$ \\
\hline GRSOD & 5.4 & $6.7(-5.8)$ & $165(+72)$ & $3114(-150)$ & $381(-110)$ & $33(-29)$ & $6.5(+0.4)$ \\
\hline $\mathrm{CNVCH}$ & 7.9 & $6.8(-0.1)$ & $187(+85)$ & $3486(+210)$ & $413(-47)$ & $39(-25)$ & $6.7(+0.5)$ \\
\hline STMCH & 37.6 & $28.5(+18.3)$ & $1230(+1120)$ & $3748(+645)$ & $409(-20)$ & $44(-20)$ & $6.7(+0.9)$ \\
\hline Tilled & 53.2 & $4.7(-3.4)$ & $188(+88)$ & $3037(-90)$ & $357(-96)$ & $40(-24)$ & $6.3(+0.3)$ \\
\hline GLY 1.5 & 8.3 & $6.4(-1.2)$ & $201(+103)$ & $3042(+370)$ & $373(-42)$ & $29(-29)$ & $6.6(+0.8)$ \\
\hline GLY 2.5 & 16.2 & $5.0(-2.8)$ & $216(+118)$ & $3988(-200)$ & $439(-86)$ & $36(-31)$ & $6.9(+0.5)$ \\
\hline NDPQT & 24.6 & $4.9(-2.7)$ & $173(+71)$ & $3297(+300)$ & $365(-98)$ & $28(-39)$ & $6.5(+0.6)$ \\
\hline $\operatorname{LSD}_{(P \leq 0.05)}{ }^{\mathrm{x}}$ & 30.1 & $12.0(10.4)$ & $163(158)$ & NS (NS) & NS (NS) & $10(\mathrm{NS})$ & NS (NS) \\
\hline
\end{tabular}

${ }^{\mathrm{z}}$ Soil nitrate-N was not measured in 1986.

yTreatment abbreviations as described in Table 1.

${ }^{x}$ Protected LSD for means of six replicates; NS = nonsignificant. 


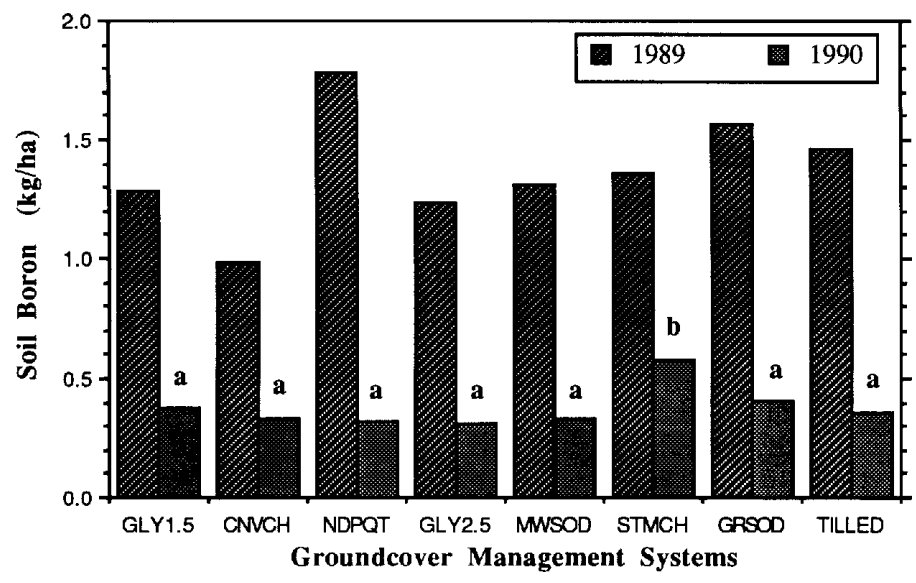

Fig. 1. Effects of groundcover management system on extractable soil B during two growing seasons (1989 and 1990) without B fertilizer applications. Each value is the mean of six replications per treatment. Columns beneath the same letters in 1990 are not significantly different at $P<0.05$; none were significantly different in 1989. orchards (Atkinson and White, 1981; Hogue and Neilsen, 1987; Robinson and O'Kennedy, 1978; Welker and Glenn, 1988). The sodgrass "Companion" mixture in the MWSOD and GRSOD plots of this study has been chosen by many fruit growers because it is purportedly less competitive with trees than other grasses, but even these low-vigor sod species caused $\mathrm{N}$ deficits in trees during most years, despite banded $\mathrm{N}$ fertilization at rates up to $166 \mathrm{~kg} \cdot \mathrm{ha}^{-1}$. The regulation of sod growth by chemical rather than mechanical means did reduce moisture competition with the trees (Merwin, 1991) but did not increase nutrient availability or yield relative to mowing. The $0.2 \mathrm{~kg} \cdot \mathrm{ha}^{-1}$ rate of glyphosate applied in GRSOD treatments during 1990 and 1991 appeared promising, because it provided equivalent grass control without the need for frequent mowing. The CNVCH "living mulch" was difficult to establish and required hand-weeding in 1987. This legume groundcover failed to increase $\mathrm{N}$ availability to the trees, exacerbated meadow vole depredation, and was associated with the lowest tree growth and yield. When we attempted to suppress resource competition and increase root nodule $\mathrm{N}$ release in the crownvetch by early and mid-summer mowing in 1991, the vetch was overrun by several

Table 3. Leaf concentrations (percent w/w) of macronutrients during mid-Aug. 1987 to 1990, and four-year mean foliar concentrations in trees within

\begin{tabular}{|c|c|c|c|c|c|c|c|c|c|c|c|c|c|c|c|}
\hline \multirow[b]{2}{*}{ Treatment } & \multicolumn{5}{|c|}{$\mathrm{N}$} & \multicolumn{5}{|c|}{$\mathrm{P}$} & \multicolumn{5}{|c|}{$\mathrm{K}$} \\
\hline & 1987 & 1988 & 1989 & 1990 & 1987-90 & 1987 & 1988 & 1989 & 1990 & 1987-90 & $\overline{1987}$ & 1988 & 1989 & 1990 & 1987-90 \\
\hline & & & & & & & & \multicolumn{8}{|c|}{ (\%) } \\
\hline MWSOD $^{2}$ & 2.08 & 2.43 & 2.06 & 1.89 & 2.12 & 0.22 & 0.20 & 0.17 & 0.20 & 0.20 & 1.61 & 1.52 & 1.44 & 1.47 & 1.51 \\
\hline GRSOD & 2.14 & 2.48 & 2.02 & 1.75 & 2.10 & 0.20 & 0.20 & 0.17 & 0.19 & 0.19 & 1.55 & 1.48 & 1.36 & 1.58 & 1.49 \\
\hline $\mathrm{CNVCH}$ & 2.38 & 2.44 & 1.97 & 1.96 & 2.26 & 0.16 & 0.21 & 0.16 & 0.18 & 0.18 & 1.64 & 1.42 & 1.36 & 1.32 & 1.43 \\
\hline STMCH & 2.52 & 2.26 & 2.09 & 2.05 & 2.23 & 0.20 & 0.20 & 0.16 & 0.17 & 0.18 & 1.94 & 2.00 & 1.71 & 1.53 & 1.79 \\
\hline Tilled & 2.44 & 2.44 & 1.94 & 1.92 & 2.19 & 0.17 & 0.20 & 0.15 & 0.15 & 0.17 & 1.57 & 1.49 & 1.37 & 1.20 & 1.41 \\
\hline GLY1.5 & 2.33 & 2.45 & 1.96 & 2.02 & 2.19 & 0.16 & 0.20 & 0.16 & 0.15 & 0.17 & 1.60 & 1.67 & 1.39 & 1.20 & 1.46 \\
\hline GLY2.5 & 2.44 & 2.51 & 2.14 & 2.10 & 2.30 & 0.18 & 0.20 & 0.16 & 0.14 & 0.17 & 1.60 & 1.66 & 1.28 & 1.19 & 1.43 \\
\hline NDPQT & 2.49 & 2.48 & 2.10 & 2.10 & 2.29 & 0.18 & 0.20 & 0.14 & 0.16 & 0.17 & 1.62 & 1.61 & 1.26 & 1.14 & 1.41 \\
\hline $\operatorname{LSD}_{(P \leq 0.05)^{\mathrm{y}}}$ & 0.23 & 0.14 & 0.18 & 0.17 & 0.09 & 0.03 & NS & 0.02 & 0.03 & 0.01 & 0.19 & 0.17 & 0.20 & 0.15 & 0.11 \\
\hline Optimal range $\mathrm{e}^{\mathrm{x}}$ & \multicolumn{5}{|c|}{$2.2-2.4$} & \multicolumn{5}{|c|}{$0.13-0.33$} & \multicolumn{5}{|c|}{$1.35-1.85$} \\
\hline
\end{tabular}

zTreatment abbreviations are as described in Table 1.

yProtected LSD for means of six replicates per treatment; NS = nonsignificant.

${ }^{x}$ Nutrient ranges recommended for apple by Dept. of Fruit and Vegetable Science at Cornell Univ. (Stiles and Reid, 1991).

Table 4. Leaf concentrations (ppm w/w) of micronutrients during mid-Aug. 1987 to 1990, and 4-year average foliar concentrations in trees within

\begin{tabular}{|c|c|c|c|c|c|c|c|c|c|c|c|c|c|c|c|}
\hline \multirow[b]{2}{*}{ Treatment } & \multicolumn{5}{|c|}{$\mathrm{Mn}$} & \multicolumn{5}{|c|}{$\mathrm{Fe}$} & \multicolumn{5}{|c|}{$\mathrm{Cu}$} \\
\hline & 1987 & 1988 & 1989 & 1990 & $1987-90$ & 1987 & 1988 & 1989 & 1990 & $1987-90$ & 1987 & 1988 & 1989 & 1990 & $1987-90$ \\
\hline & & & & & & & & & & & & $(p p m)$ & & & \\
\hline MWSOD $^{2}$ & 52 & 276 & 148 & 48 & 131 & 83 & 91 & 82 & 61 & 79 & 5.5 & 6.5 & 4.8 & 5.4 & 5.5 \\
\hline GRSOD & 56 & 291 & 137 & 55 & 135 & 83 & 88 & 89 & 62 & 81 & 5.8 & 6.9 & 4.7 & 4.8 & 5.6 \\
\hline $\mathrm{CNVCH}$ & 47 & 393 & 151 & 47 & 159 & 77 & 98 & 83 & 63 & 80 & 6.3 & 5.4 & 5.0 & 5.4 & 5.5 \\
\hline STMCH & 72 & 277 & 145 & 54 & 137 & 79 & 80 & 84 & 62 & 76 & 6.9 & 6.0 & 4.3 & 5.5 & 5.7 \\
\hline Tilled & 58 & 279 & 138 & 45 & 130 & 81 & 94 & 78 & 57 & 77 & 6.8 & 7.4 & 5.4 & 5.6 & 6.3 \\
\hline GLY1.5 & 50 & 258 & 164 & 48 & 130 & 79 & 80 & 84 & 62 & 76 & 6.2 & 7.8 & 4.9 & 5.5 & 6.1 \\
\hline GLY2.5 & 49 & 254 & 179 & 45 & 132 & 74 & 81 & 92 & 61 & 77 & 7.2 & 7.8 & 5.3 & 5.8 & 6.5 \\
\hline NDPQT & 53 & 259 & 162 & 54 & 132 & 76 & 80 & 81 & 69 & 76 & 6.9 & 7.6 & 4.8 & 5.8 & 6.2 \\
\hline $\operatorname{LSD}_{(P \leq 0.05)^{\mathrm{y}}}^{\mathrm{y}}$ & 12 & 54 & NS & NS & 19 & NS & 11 & NS & NS & NS & 1.1 & 0.8 & NS & NS & 0.4 \\
\hline
\end{tabular}

Treatment abbreviations are as described in Table 1 .

'Protected LSD for means of six replicates per treatment; NS = nonsignificant.

${ }^{x}$ Nutrient ranges recommended for apple by Dept. of Fruit and Vegetable Science at Cornell Univ. (Stiles and Reid, 1991). 
weeds, especially quackgrass (Agropyron repens L.).

The differences in TCSA increase, nutrition, and yield between the GLY1.5 and 2.5-m-wide tree-row strips were generally not significant at $P<0.05$. However, there was a trend toward somewhat greater growth, nutrient uptake, and yield of trees in the wider glyphosate band, which is consistent with previous reports by others (Welker and Glenn, 1985, 1989). A comparison of equal width strips of pre-emergence (NDPQT) and postemergence (GLY2.5) herbicides indicated no significant differences in tree growth, nutrition, or yield, despite our observations that soil physical conditions and rainfall infiltration were more favorable in the sparse weed-cover of GLY2.5 plots than in the bare soil of NDPQT plots (Merwin et al., 1994). A persistent moss groundcover and annual weed regrowth between herbicide applications in the glyphosate plots appeared to provide some of the soil conservation benefits of the "killed sod" system described by Welker and Glenn (1988).

The higher soil nitrate concentrations in tilled plots in 1990 apparently did not increase leaf $\mathrm{N}$ relative to other GMS treatments, and probably represented a transient increase in $\mathrm{N}$ miner-

Table 3 continued

each groundcover management system.

\begin{tabular}{|c|c|c|}
\hline $\mathrm{Ca}$ & & $\mathrm{Mg}$ \\
\hline
\end{tabular}

\begin{tabular}{cccccccccc}
0.91 & 1.04 & 0.90 & 1.03 & 0.97 & 0.40 & 0.42 & 0.33 & 0.32 & 0.37 \\
0.90 & 1.04 & 0.83 & 1.04 & 0.95 & 0.43 & 0.45 & 0.33 & 0.33 & 0.38 \\
0.91 & 0.99 & 0.94 & 1.03 & 0.97 & 0.40 & 0.40 & 0.37 & 0.37 & 0.38 \\
0.99 & 0.82 & 0.78 & 1.11 & 0.92 & 0.36 & 0.32 & 0.30 & 0.32 & 0.32 \\
0.94 & 1.08 & 0.78 & 1.04 & 0.96 & 0.41 & 0.44 & 0.33 & 0.38 & 0.39 \\
0.92 & 0.89 & 0.87 & 1.03 & 0.92 & 0.41 & 0.40 & 0.33 & 0.36 & 0.37 \\
0.89 & 0.93 & 0.84 & 1.00 & 0.92 & 0.39 & 0.40 & 0.34 & 0.36 & 0.38 \\
0.87 & 0.92 & 0.75 & 1.09 & 0.91 & 0.40 & 0.40 & 0.32 & 0.37 & 0.37 \\
NS & 0.14 & NS & NS & NS & NS & 0.03 & 0.04 & 0.03 & 0.02 \\
& \multicolumn{3}{c}{$1.3-2.0$} & & & & $0.35-0.50$ &
\end{tabular}

Table 4 continued

each groundcover management system.

$\begin{array}{lllllllllll}1987 & 1988 & 1989 & 1990 & 1987-90 & & 1987 & 1988 & 1989 & 1990 & 1987-90\end{array}$

$\begin{array}{rrrrrrrrrr}68 & 52 & 24 & 12 & 39 & 72 & 35 & 30 & 31 & 42 \\ 65 & 52 & 22 & 11 & 38 & 71 & 36 & 30 & 31 & 42 \\ 68 & 62 & 24 & 11 & 41 & 73 & 38 & 27 & 29 & 42 \\ 66 & 49 & 20 & 12 & 36 & 87 & 35 & 27 & 27 & 44 \\ 69 & 52 & 23 & 12 & 37 & 72 & 36 & 30 & 30 & 42 \\ 79 & 50 & 27 & 13 & 42 & 79 & 35 & 30 & 28 & 43 \\ 80 & 51 & 27 & 13 & 43 & 90 & 36 & 30 & 27 & 46 \\ 79 & 48 & 24 & 13 & 41 & 80 & 36 & 28 & 29 & 44 \\ \text { NS } & 6 & \text { NS } & \text { NS } & \text { NS } & 12 & \text { NS } & 2 & 2 & \text { NS } \\ & & 35-50 & & & & & 35-50 & & \\ \end{array}$

alization as soil organic matter oxidized after cultivation. As reported by Merwin et al. (1994), the soil organic matter content in tilled and NDPQT treatments declined by $18 \%$ and $13 \%$, respectively, after 5 years of treatments. The STMCH treatment allowed excellent tree growth, nutrient uptake, and fruit yield. The increased soil $\mathrm{K}$ and $\mathrm{P}$ in mulched plots were especially noteworthy and consistent with other reports of mulching benefits (Pool et al., 1990; Shribbs and Skroch, 1986a, 1986b; White and Holloway, 1967). After 2 years without $K$ fertilizers, the trees in NDPQT and GLY plots bearing substantial croploads in 1990 had suboptimal leaf $\mathrm{K}$, while leaf $\mathrm{K}$ remained within optimal range in the heavily cropped trees of STMCH plots and the lighter-cropped MWSOD and GRSOD trees. These observations emphasize the effect of cropload on leaf $\mathrm{K}$, and the possibility that soil $\mathrm{K}$ availability can be maximized by straw mulching. However, the straw-mulch GMS was the most expensive to establish and maintain, and tree mortalities caused by phytophthora root disease and meadow voles were unacceptably high in STMCH plots, despite extensive preplant site drainage improvements and a rigorous vole control program. In other sites where meadow voles are less problematic, and soil texture, drier climate, or both minimize the likelihood of phytophthora root disease, straw-mulch GMS might provide important edaphic benefits.

In a comprehensive review of the literature, Hogue and Neilsen (1987) remarked on the insufficient information about soil management system impacts on micronutrient supply and uptake in orchards. We observed a precipitous decline in leaf $\mathrm{Mn}, \mathrm{Cu}, \mathrm{B}$, and $\mathrm{Zn}$ in all GMS treatments during the 2 years without additions of these nutrients in fungicides or fertilizers. This indicates the need for supplemental provisions of these essential elements regardless of soil management systems in bearing orchards of the northeastern United States. Except for the apparent increase in $\mathrm{Cu}$ uptake by trees in herbicide and tilled plots with intermediate soil water content during Summer 1988, there appeared to be few differential effects of GMS on soil micronutrient availability in most years of our study. This elevated $\mathrm{Cu}$ uptake may have been related to enhanced release of complexed $\mathrm{Cu}$ from soil organic matter oxidized as a consequence of the more frequent wetting-drying cycles and soil temperature fluctuations in these GMSs (Barber, 1984; Merwin et al., 1994).

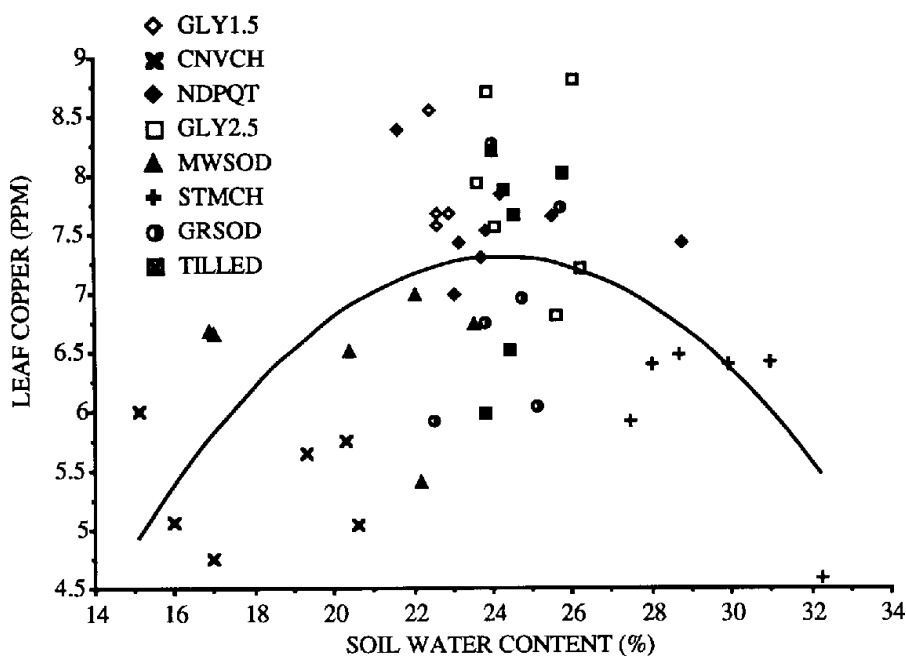

Fig. 2. The relationship between average soil water content during the growing season and leaf $\mathrm{Cu}$ concentrations in 1988. Regression model $(\mathrm{y}=-9.41+1.38 \mathrm{x}$ $-0.028 \mathrm{x}^{2}$ ) for standardized values was significant at $P<0.001$, linear and quadratic trends at $P<0.001$. 
Table 5. Analysis of variance table, F values, and standardized regression coefficients of the four edaphic variables remaining in a stepwise regression of 1990 fruit yield on essential soil nutrients and organic matter, leaf nutrient concentrations, and yearly average soil water content under different groundcover management systems during three growing seasons preceding the 1990 crop.

\begin{tabular}{lcccc}
\hline \hline Source & $\mathrm{df}^{z}$ & Sum of squares & F value & Adjusted $r^{2}$ \\
\hline Regression & 4 & 30.4 & 23.6 & 0.68 \\
Residual & 39 & 12.6 & &
\end{tabular}

Variables in model ${ }^{\mathrm{y}}$ Standardized $b$ coefficient Partial F value

Mean soil water content, 1988

0.42

18.8

Leaf $\mathrm{N}$ concentration, 1990

0.38

15.6

Leaf B concentration, 1990

$-0.38$

14.9

Soil organic matter content, 1990

$-0.38$

15.5

${ }^{\mathrm{z}}$ Four soil samples were excluded from this regression model because of heavy metal contaminants unrelated to treatments.

${ }^{y}$ F-to-enter and remove variables from regression model set $\geq 4.0$, using a forward-backward stepwise elimination procedure. Correlation coefficients between independent variables in model were not significant at $P<0.05$ for $43 \mathrm{df}$.

There have been many investigations of the effect of irrigation and $\mathrm{N}$ fertilization on fruit tree growth and nutrient uptake under different soil management systems (Atkinson et al., 1978; Hipps et al., 1990; Hogue and Neilsen, 1987; Miller and Glenn, 1985). Previous reports have indicated that frequent irrigation and/or $\mathrm{N}$ fertilization rates greater than the $166 \mathrm{~kg} \cdot \mathrm{ha}^{-1}$ applied in our study are required to compensate for turf or weed $\mathrm{N}$ competition with young fruit trees. Our observations were consistent with previous reports that soil moisture, soil and leaf $\mathrm{N}$ concentrations, and tree growth were reduced under legume and grass groundcovers relative to herbicide GMSs (Shribbs and Skroch, 1986a, 1986b). We did not observe the decrease in soil $\mathrm{pH}$ under herbicides relative to vegetation groundcovers that others have reported (Atkinson and White, 1981; Haynes, 1981; Lipecki et al., 1985). However, the application of $12 \mathrm{Mg}$ of dolomitic lime per hectare before establishing this experiment in 1985 probably explains the observed soil $\mathrm{pH}$ increase after 5 years in all GMSs.

Average soil water content during the drought summer of 1988 was a better predictor of 1990 yield in our multiple regression model than soil water supply during the more recent 1989 and 1990 growing seasons (with adequate rainfall). This illustrates the multi-year carryover effects that previous episodes of drought stress can have on flower bud initiation and subsequent yields of perennial tree fruit. Current season leaf $\mathrm{N}$ was a significant predictor of yield in 1990, and indicates the impact of $\mathrm{N}$ interference in the sodgrass treatments. The negative regression coefficient for leaf $B$ and yield was interpreted as a result of the increased canopy and crop demand for B in the higher yielding treatments (Stiles and Reid, 1991). We suggest that the negative correlation between soil organic matter and yield was an artifact reflecting the lower yields in the CNVCH, MWSOD, and GRSOD treatments (in which soil organic matter content increased) relative to the higheryielding NDPQT plots (in which organic matter decreased). These observations indicate that soil water availability, N and B uptake, crop load, and other variables associated with different GMSs, are all important factors in orchard establishment and productivity.

The interactions between young apple trees, groundcover vegetation, and edaphic conditions in orchards are obviously complex, and the relative economic and environmental costs and benefits of each GMS can vary substantially in response to local weather patterns and successional processes in the perennial crop system. Alternative groundcover management systems involve a number of tradeoffs between short- and long-term advantages or disadvantages, all of which must be considered and compared in developing sustainable orchard floor management systems.

\section{Literature Cited}

Atkinson, D., M.G. Johnson, D. Mattam, and R. Mercer. 1978. The effect of orchard soil management on the uptake of nitrogen by established apple trees. J. Sci. Food Agr. 30:129-135.

Atkinson, D. and G.C. White. 1981. The effects of weeds and weed control on temperate fruit orchards and their environment, p. 415-428. In: J.M. Thresh (ed.). Pests, pathogens and vegetation: The role of weeds and wild plants in the ecology of crop pests and diseases. Pittman, London. Barber, S.A. 1984. Soil nutrient bioavailability. Wiley, New York. p. 313323.

Greweling, T. and M. Peech. 1965. Chemical soil tests. Cornell Univ. Agr. Expt. Sta. Ithaca, N.Y. Bul. no. 960.

Haynes, R.J. 1980. Influence of soil management practice on the orchard agro-ecosystem. Agroecosystems 6:3-32.

Haynes, R.J. 1981. Soil pH decrease in the herbicide strip of grassed-down orchards. Soil Sci. 132:274-278.

Hipps, N.A., M.S. Ridout, and D. Atkinson. 1990. Effects of alley sward width, irrigation and nitrogen fertiliser on growth and yield of 'Cox's Orange Pippin' apple trees. J. Sci. Food Agr. 53:159-168.

Hogue, E.J. and G.H. Neilsen. 1987. Orchard floor vegetation management, p. 377-430. In: J. Janick (ed.). Horticultural reviews. vol. 9. Avi Publishers, Westport, Conn.

Lipecki, J., H. Baczewska, and U. Kiebinska. 1985. Soil properties in inter-rows of apple orchard as related to soil management. Fruit Sci. Rpt. 12:62-72.

Merwin, I.A. 1990. Alternatives in orchard ground-cover management: Effects on apple tree growth and nutrition, soil physical conditions, phytophthora root disease, and relative weed species abundance. PhD Diss. Cornell Univ., Ithaca, N.Y.

Merwin, I.A. 1991. Alternatives in orchard groundcover management. Proc. 136th Annu. Mtg. New York State Hort. Soc. 136:71-84.

Merwin, I.A., W.F. Wilcox, and W.C. Stiles. 1992. Influence of orchard ground cover management on the development of phytophthora crown and root rots of apple. Plant Dis. 76:199-205.

Merwin, I.A., W.C. Stiles, and H.M. van Es. 1994. Orchard groundcover management system impacts on soil physical properties. J. Amer. Soc. Hort. Sci. 119:216-222

Miller, S.S. and D.M. Glenn. 1985. Influence of various rates of $\mathrm{Ca}\left(\mathrm{NO}_{3}\right)_{2}$ fertilizer and soil management on young apple trees. J. Amer. Soc. Hort. Sci. 110:237-243.

National Research Council. 1989. Problems in U.S. agriculture, p. 89134. In: Alternative agriculture. Rpt. Natl. Res. Council, Natl. Acad. of Sci. Press, Washington, D.C.

Pool, R.M., R.M. Dunst, and A.M. Lakso. 1990. Comparison of sod, mulch, cultivation, and herbicide floor management practices for grape production in nonirrigated vineyards. J. Amer. Soc. Hort. Sci. 115:872877.

Robinson, D.W. and N.D. O'Kennedy. 1978. The effect of overall herbicide systems of soil management on the growth and yield of apple 
trees 'Golden Delicious'. Sci. Hort. 9:127-136.

Shribbs, J.M. and W.A. Skroch. 1986a. Influence of 12 ground cover systems on young 'Smoothee Golden Delicious' apple trees: I. Growth. J. Amer. Soc. Hort. Sci. 111:525-528.

Shribbs, J.M. and W.A. Skroch. 1986b. Influence of 12 ground cover systems on young 'Smoothee Golden Delicious' apple trees: II. Nutrition. J. Amer. Soc. Hort. Sci. 111:529-533.

Skroch, W.A. and J.M. Shribbs. 1986. Orchard floor management: An overview. HortScience 21:390-394.

Stiles, W.C. and W.S. Reid. 1991. Orchard nutrition management. Cornell Univ. Coop. Ext., Ithaca, N.Y. Info. Bul. no. 219.
White, G.C. and R.C. Holloway. 1967. The influence of simazine or a straw mulch on the establishment of apple trees in grassed down or cultivated soil. J. Hort. Sci. 42:377-389.

Welker W.V. and D.M. Glenn. 1985. The relationship of sod proximity to the growth and nutrient composition of newly-planted peach trees. HortScience 20:417-418.

Welker W.V. and D.M. Glenn. 1988. Growth responses of peach and changes in soil characteristics with sod and conventional planting systems. J. Amer. Soc. Hort. Sci. 113:652-656.

Welker, W.V. and D.M. Glenn. 1989. Sod proximity influences the growth and yield of young peach trees. J. Amer. Soc. Hort. Sci. 114:856-859. 